\title{
Hydroxystilbenes of Eucalyptus wandoo
}

\author{
By D. E. HATHWAY AND J. W. T. SEAKINS \\ The British Leather Manufacturers' Research Association, Milton Park, Egham, Surrey
}

(Received 11 December 1958)

The heartwood and sapwood of the Australian myrtaceous tree Eucalyptus wandoo is used as a commercial tanning material. In preliminary experiments with the ether-soluble extractives three substances were detected which show an intenseblue fluorescence in ultraviolet light, which are red with tetrazotized benzidine and which may be hydroxystilbenes. All seven hydroxystilbenes (Table 1) which have been isolated from the Monoand Di-cotyledonae possess a resorcinol nucleus. In the Gymnospermae, the 3:5-dihydroxystilbenes of the genus Pinus serve as taxonomic tracers in the Pinaceae, they protect the heartwoods from wood-rotting fungi and insects and they prevent the acid-sulphite pulping of the logs (Hägglund, 1941) by forming insoluble resins with the lignin. Hydroxystilbenes have not previously been found in the Myrtaceae.

\section{EXPERIMENTAL}

Evaporations were carried out in $\mathrm{N}_{2}$ under reduced pressure below $35^{\circ}$. Melting points were determined on a Kofler block. Separation of the ether-soluble phenols of Eucalyptus wandoo heartwood. Heartwood chips (500 g.) were extracted in a Soxhlet apparatus with methanol (1.5 l.) for $10 \mathrm{hr}$. and $400 \mathrm{ml}$. of water was added to the extract. Partial evaporation left a solution $(300 \mathrm{ml}$.) which was continuously extracted for $30 \mathrm{hr}$. with four changes of acetic acid-free ethyl acetate in a Schacherl apparatus. Evaporation of the solvent left a solid residue which was dried over $\mathrm{P}_{2} \mathrm{O}_{5}$ at $20^{\circ}$ in vacuo for $16 \mathrm{hr}$. The ethyl acetatesoluble fraction $(25 \cdot 2 \mathrm{~g}$.) constituted $5 \cdot 6 \%$ (by wt.) of the moisture-free heartwood. An aqueous solution (300 ml.) of this fraction was continuously extracted for $24 \mathrm{hr}$. with peroxide-free ether in the Schacherl apparatus, ice-water being pumped through the condenser. Evaporation of the solvent left a solid residue (18.8 g.) which was dried over $\mathrm{P}_{2} \mathrm{O}_{5}$ at $20^{\circ}$ in vacuo for $16 \mathrm{hr}$. Yellow wax was removed from this fraction (18.8 g.) by extraction with benzene in a Soxhlet apparatus, and the residual material (16.6 g.), which is known as the ether-soluble phenols, constitutes $3.7 \%$ (by wt.) of the moisture-free heartwood.

Direct extraction of the initial aqueous solution with ether caused excessive frothing, which was obviated by intermediate extraction with ethyl acetate. Ether extraction of the heartwood chips $(500 \mathrm{~g}$.) afforded a residue $(2 \cdot 2 \mathrm{~g}$.) which consisted principally of yellow wax $(>2 \cdot 0 \mathrm{~g}$.).

Ether-soluble phenols from the sapwood and different locations in the heartwood. Small samples of drillings were taken from a transverse section through a 100-year-old primary limb which was $50 \mathrm{~cm}$. in diameter. Samples were removed from the sapwood, the centre of the heartwood and at two locations situated at $1 \mathrm{~cm}$. and $10 \mathrm{~cm}$. inside the heartwood-sapwood boundary.

\section{Paper chromatography}

Chromatograms were run at $25^{\circ}$ and dried at room temperature unless stated otherwise. Methanolic solutions $(0.5 \% ; 5 \mu \mathrm{l}$.) of the ether-soluble phenols and of fractions from the columns were applied to Whatman no. 2 filter papers, $25.5 \mathrm{~cm}$. square, and chromatographed by the ascending method with $\mathrm{N}$-acetic acid as first-way solvent and butan-1-ol-acetic acid-water $(6: 1: 2$, by vol.) as the second. Phenols were detected by their fluorescence in ultraviolet light, by the $\mathrm{FeCl}_{3}-\mathrm{K}_{3} \mathrm{Fe}(\mathrm{CN})_{6}$ and vanillin reagents (Hathway, 1958), and by the tetrazotized benzidine reagent (Koch \& Krieg, 1938; Linstedt, 1950). Catechin and gallic acid were resolved with butan-1-olacetic acid-water $(6: 1: 2$, by vol.) as the first-way solvent system and $m$-cresol-acetic acid-water (50:1:49, by vol.) as the second. These chromatograms were dried at $70^{\circ}$.

Single-way chromatography of the hydroxybenzoic acids was carried out in N-acetic acid, butan-1-ol-acetic acidwater (6:1:2, by vol.) and benzyl alcohol-tert.-butanolpropan-2-ol-water (3:1:1:1, by vol.) mixture containing

Table 1. Distribution of hydroxystilbenes in the Mono- and Di-cotyledonae

Family

Liliaceae

Leguminosae

Moraceae

Polygonaceae

24
Stilbene derivative

3:5:4'-Trihydroxy-

3:5:2':4'-Tetrahydroxy-

3:5-Dimethoxy-4'-hydroxy-

3:5:3':4'-Tetrahydroxy-

$3: 5: 3^{\prime}: 4^{\prime}: 5^{\prime}$-Pentahydroxy-

$3: 5: 2^{\prime}: 4^{\prime}$-Tetrahydroxy-

2-Homogeranyl-3:5:2':4'-tetrahydroxy$4^{\prime}$-Methoxy-3:5:3'-trihydroxy-
Reference

Takaoka $(1940 a, c)$

Späth \& Schläger (1940); King, Cotterill, Godson, Jurd \& King (1953)

King, King, Godson \& Manning (1956)

Barnes \& Gerber (1955); Mongolsuk,

Robertson \& Towers (1957)

King \& Grundon (1949).

Kawamura (1938)

Bioch. 1959, 72 
$1.8 \%(\mathrm{w} / \mathrm{v})$ of formic acid (Stark, Goodban \& Owens, 1951) respectively. The chromatograms with the third solvent system were dried at $70^{\circ}$.

Sugars were chromatographed by the single-way descending method (Hathway \& Seakins, 1958).

\section{Separation of compounds $B_{1}$ and $B_{2}$ by chromatography on a cellulose column}

Use was made of a column $(60 \mathrm{~cm} . \times 5 \mathrm{~cm}$.) of Solka Floc cellulose (Hathway, 1958) which had been mixed with an equal weight of acid-washed kieselguhr (British Drug Houses Ltd.) (Grassmann, Deffner, Schuster \& Pauckner, 1956). A methanolic solution (250 ml.) of ether-soluble phenols (100 g.) was made into a slurry with Solka Floc cellulose $(100 \mathrm{~g}$.$) and the solvent evaporated. The powder$ obtained was made into a slurry with $0.5 \mathrm{~N}$-acetic acid and transferred to the top of the column, which was eluted at a pressure of $25 \mathrm{~cm}$. $\mathrm{Hg}$ with $0.5 \mathrm{~N}$-acetic acid which contained $0.002 \%$ of $\mathrm{SO}_{2}$. The flow-rate was $120 \mathrm{ml} . / \mathrm{hr}$.; $500 \mathrm{ml}$. fractions of eluate were collected. For the evaporation of large volumes of eluate, a circulatory cycloneevaporator (no. 20EF, Quickfit and Quartz Ltd., Stone, Staffs.) was used.

Traces of chlorogenic acid and $p$-coumarylquinic acid and small quantities of catechin, gallic acid and other unknown phenols were eluted in the first 41 . of eluate.

The succeeding $500 \mathrm{ml}$. of eluate deposited crystals $\left(0 \cdot 6\right.$ g.) of pure compound $B_{1}$ on standing. Evaporation of the next 5.5 l. of eluate, together with the mother liquor from which compound $B_{1}$ had been deposited, afforded a brown glass $(20 \mathrm{~g}$.) from which a further quantity of compound $\mathrm{B}_{1}$ was obtained by polyamide-column chromatography.

Elution of the column with methanol (2 l.) and evaporation of the eluate obtained gave a coloured residue (52 g.), m.p. about $250^{\circ}$, of impure compound $B_{2}$. Acetylation by the acetic anhydride-pyridine method gave compound $B_{2}$ triacetate, which crystallized from benzene-light petroleum (b.p. $\left.80-100^{\circ}\right)(1: 1, v / v)$ as glistening plates, m.p. 118-119 (Found: $\mathrm{C}, 68 \cdot 3 ; \mathrm{H}, 5 \cdot 2 ; \mathrm{CH}_{3} \cdot \mathrm{CO}, 35 \cdot 4$. Calc. for $\mathrm{C}_{20} \mathrm{H}_{18} \mathrm{O}_{6}$ : $\mathrm{C}, 67 \cdot 8 ; \mathrm{H}, 5 \cdot 1 ; \mathrm{CH}_{3} \cdot \mathrm{CO}, 36.4 \%$ ), and from aqueous ethanol fine needles, m.p. 118-119 ${ }^{\circ}$. Alkaline hydrolysis of the triacetate under $\mathrm{N}_{2}$ gave compound $\mathrm{B}_{2}$, which crystallized from $2 \mathrm{~N}$-acetic acid in felted needles (27 g.), m.p. $264^{\circ}$ on a preheated Kofler block, $\lambda_{\max }$ in ethanol $305 \mathrm{m \mu}$ ( $\log \epsilon 4.45) ; 220 \mathrm{~m} \mu$ (log $\epsilon$ 4.32) (Found: C, 73.5; H, 4.9. Calc. for $\mathrm{C}_{14} \mathrm{H}_{12} \mathrm{O}_{3}: \mathrm{C}, 73 \cdot 7 ; \mathrm{H}, 5 \cdot 3 \%$ ). Crystallization of the triacetate removed contaminating methoxyl-containing impurity from compound $\mathrm{B}_{\mathbf{2}}$.

Purification of compound $B_{1}$ by chromatography on polyamide column. A column $(30 \mathrm{~cm} . \times 3.5 \mathrm{~cm}$.) of Perlonpulver 'feinst' (Werk Bobingen A.-G.), prepared by the method of Grassmann, Endres, Pauckner \& Mathes (1957), was used. A solution of crude compound $\mathrm{B}_{1}(\mathbf{4} \mathrm{g}$.) in methanol-water $(1: 1, v / v)$ was adsorbed on to the column, which was then eluted with the methanol-water $(1: 1, v / v)$. The progress down the column of a sharp band of compound $B_{1}$ was observed by its fluorescence in ultraviolet light, and $500 \mathrm{ml}$. of eluate was collected, and evaporated to $50 \mathrm{ml}$., which deposited clusters of needles $\left(0.5 \mathrm{~g}\right.$.) of compound $B_{1}$, m.p.'s $142^{\circ}$ (loss of $\mathrm{H}_{2} \mathrm{O}$ ), $210^{\circ}$; $[\alpha]_{\mathrm{D}}^{22}-68.5^{\circ}$ in methanol $(c, 2 \cdot 6)$; light-absorption max. in ethanol $305 \mathrm{~m} \mu(\log \epsilon$ 4.45); $220 \mathrm{~m} \mu(\log \epsilon 4.32)$ (Found: $\mathrm{C}, 58 \cdot 7$; H, 5.8; loss at $150^{\circ}, 4 \cdot 2$. $\mathrm{C}_{20} \mathrm{H}_{22} \mathrm{O}_{8}, \mathrm{H}_{2} \mathrm{O}$ requires $\mathrm{C}, 58 \cdot 8 ; \mathrm{H}, 5 \cdot 9 ; \mathrm{H}_{2} \mathrm{O}$,
$4.4 \%$ ). The hexa-acetate crystallized from methanol in fine needles, m.p. $107^{\circ} ;[\alpha]_{\mathrm{D}}^{22}-21^{\circ}$ in acetone $(c, 4 \cdot 4)$ (Found: C, 59.3; H, 5.3; $\mathrm{CH}_{3} \cdot \mathrm{CO}, 40 \cdot 1 . \mathrm{C}_{32} \mathrm{H}_{34} \mathrm{O}_{14}$ requires $\mathrm{C}, 59 \cdot 8$; $\mathrm{H}, 5 \cdot 3 ; \mathrm{CH}_{3} \cdot \mathrm{CO}, 39 \cdot 9 \%$ ).

\section{Structure of compound $\boldsymbol{B}_{2}$}

Compound $\mathrm{B}_{2}(350 \mathrm{mg}$.) in methanol $(20 \mathrm{ml}$.) was shaken in $\mathrm{H}_{2}$ with $10 \%$ palladinized charcoal (150 mg.): $1 \mathrm{~mol}$. prop. was taken up during $30 \mathrm{~min}$. Isolation by evaporation and crystallization from water yielded dihydro- $B_{2}$ (325 mg.), as needles of the monohydrate, m.p. $107^{\circ}$, which give the vanillin reaction. Loss of water at $100^{\circ}$ (Found: 7.7. Calc. for $\mathrm{C}_{14} \mathrm{H}_{14} \mathrm{O}_{3}, \mathrm{H}_{2} \mathrm{O}: 7 \cdot 3 \%$ ) from the monohydrate gave anhydrous dihydro- $\mathrm{B}_{2}$, m.p. $160^{\circ}$, light-absorption max. in ethanol $280 \mathrm{~m} \mu(\log \epsilon 3.47)$ (Found: $\mathrm{C}, 72 \cdot 7 ; \mathrm{H}$, 6.0. $\mathrm{C}_{14} \mathrm{H}_{14} \mathrm{O}_{3}$ requires: $\mathrm{C}, 73 \cdot 0 ; \mathrm{H}, 6 \cdot 1 \%$ ). Dihydro- $\mathrm{B}_{2}$ was characterized as the tri-acetate, which crystallized from methanol in needles, m.p. $58^{\circ}$ (Found: $\mathrm{C}, 67.6 ; \mathrm{H}, 5.8$; $\mathrm{CH}_{3} \cdot \mathrm{CO}, 35 \cdot 7 . \mathrm{C}_{20} \mathrm{H}_{20} \mathrm{O}_{6}$ requires $\mathrm{C}, 67 \cdot 4 ; \mathrm{H}, 5 \cdot 6 ; \mathrm{CH}_{3} \cdot \mathrm{CO}$, $36 \cdot 2 \%$ ).

Treatment of compound $\mathrm{B}_{2}$ with diazomethane gave the tri- $O$-methyl ether, which was purified by distillation at $180^{\circ}$ and $1 \mathrm{~mm} . \mathrm{Hg}$ and twice crystallized from methanol as plates, m.p. $55-57^{\circ}$ (Found: $\mathrm{C}, \mathbf{7 5} \cdot 2 ; \mathrm{H}, 6 \cdot 5 ; \mathrm{OMe}, 33 \cdot 5$. Calc. for $\mathrm{C}_{17} \mathrm{H}_{18} \mathrm{O}_{3}: \mathrm{C}, 75 \cdot 5 ; \mathrm{H}, 6 \cdot 7 ; \mathrm{OMe}, 34 \cdot 4 \%$ ). The m.p. $\left(264^{\circ}\right)$ of compound $B_{2}$ was not depressed by admixture with a specimen of $3: 5: 4^{\prime}$-trihydroxystilbene, m.p. $263^{\circ}$, prepared by the method of Takaoka $(1940 b, d)$.

\section{Structure of compound $B_{1}$}

A methanolic solution $\left(20 \mathrm{ml}\right.$.) of compound $B_{1}(500 \mathrm{mg}$.) was shaken in $\mathrm{H}_{2}$ with $10 \%$ palladinized charcoal (150 mg.) for $30 \mathrm{~min}$., when the uptake of $\mathrm{H}_{2}$ was $1 \mathrm{~mol}$. prop. Evaporation of the solvent gave a solid which, after crystallization from toluene containing a small proportion of ethanol, yielded prisms of dihydro- $B_{1}$, m.p. $208^{\circ}$, $[\alpha]_{\mathrm{D}}^{22}-36^{\circ}$ in acetone $(c, 2 \cdot 5)$, light-absorption $\max$, in ethanol $280 \mathrm{~m} \mu$ (log $\epsilon$ 3.47) (Found: C, 60.6; H, 6.1. $\mathrm{C}_{20} \mathrm{H}_{24} \mathrm{O}_{3}$ requires $\mathrm{C}, 61 \cdot 2 ; \mathrm{H}, 6 \cdot 1 \%$ ), which slowly develop a red with vanillin reagent.

Permanganate oxidation. Finely powdered $\mathrm{KMnO}_{4}$ (1.8 g.) was added gradually to an acetone solution (100 ml.) of the hexa-acetate $\left(0.6 \mathrm{~g}\right.$.) of compound $B_{1}$, and the reaction was allowed to proceed at room temperature for $1 \mathrm{hr}$., when excess of $\mathrm{KMnO}_{4}$ was destroyed with $\mathrm{SO}_{2}$. The reaction mixture was evaporated and the residue was extracted with ether in a Soxhlet apparatus. Hydrolysis of the ether extract was effected by treatment for $\mathbf{3 0} \mathrm{min}$. on the boiling-water bath with $\mathrm{N}-\mathrm{NaOH}$ under $\mathrm{N}_{2}$. A mixture of phenolic acids (200 mg.) was isolated from the acidified reaction mixture with ether. Fractional crystallization from water (with charcoal) gave an acid, m.p. $165^{\circ}$, which when sublimed and further crystallized afforded $p$-hydroxybenzoic acid (50 mg.), m.p. $213^{\circ}$, undepressed by admixture with an authentic specimen, m.p. $215^{\circ}$. From the original mother liquors was isolated 3:5-dihydroxybenzoic acid (50 mg.), m.p. $225^{\circ}$, undepressed by admixture with an authentic specimen, m.p. $225^{\circ}$. The identity of these two acids was confirmed by paper chromatography in three solvent systems.

Hydrolysis. Treatment of compound $B_{1}(194 \mathrm{mg}$.) with $\mathrm{N}-\mathrm{H}_{2} \mathrm{SO}_{4}(10 \mathrm{ml}$.) on the boiling-water bath for $30 \mathrm{~min}$. effected hydrolysis. Extraction with ether afforded 3:5:4'-trihydroxystilbene (96 mg.), m.p. $264^{\circ}$, undepressed 
by admixture with an authentic specimen, m.p. $264^{\circ}$. The residual aqueous solution was percolated $(0.5 \mathrm{ml} . / \mathrm{min}$.) through a column (bed volume $13 \mathrm{ml}$.) of De-Acidite Gr anion-exchange resin ( $1.5 \mathrm{mg}$.equiv. $/ \mathrm{ml}$.) in the free base form, and the column was washed free from sugar with $40 \mathrm{ml}$. of water. Partial evaporation of the eluate gave a solution $(2 \mathrm{ml}$.), which was treated with phenylhydrazine (180 mg.) and acetic acid $(0 \cdot 2 \mathrm{ml}$.). Characteristic sheaves of glucosazone (200 mg.), m.p. $208^{\circ}$ (decomp.), were formed, which had the same shape and m.p. as an authentic specimen. Oxidation afforded glucosotriazole, m.p. 195$196^{\circ}$, undepressed by admixture with an authentic specimen. The identity of the sugar in the eluate with glucose was further demonstrated by paper chromatography in three solvent systems. The molar ratio of aglucone to glucoside was $1: 1$ (Found: $49 \%$ aglucone. Calc. $56 \%$ ).

Enzymic hydrolysis. Compound $\mathrm{B}_{1}$ (100 mg.) was hydrolysed at $25^{\circ}$ for $16 \mathrm{hr}$. with a solution containing emulsin, prepared from almonds by the method of Mann \& Saunders (1938). 3:5:4'-Trihydroxystilbene (55 mg.), m.p. 264 ${ }^{\circ}$, was isolated in $100 \%$ yield with ether from the acidified digest. Similar enzymic hydrolysis of dihydro- $B_{1}$ gave dihydro$B_{2}$, i.e. 1-(3:5-dihydroxyphenyl)-2-(4-hydroxyphenyl)-ethane, m.p. and mixed m.p. $160^{\circ}$.

Hydrolysis of the methylation product. A methanolic solution (50 ml.) of compound $B_{1}(1.5 \mathrm{~g}$.) was treated with an excess of diazomethane for $24 \mathrm{hr}$., when the excess was destroyed. The attempted crystallization of the reaction product from water afforded an amorphous powder $(1 \mathrm{~g}$.$) ,$ m.p. about $160^{\circ}$. Hydrolysis of the methanolic solution $\left(80 \mathrm{ml}\right.$.) of this product with $4 \mathrm{~N}-\mathrm{H}_{2} \mathrm{SO}_{4}$ on the boilingwater bath under $\mathrm{N}_{2}$ for $4 \mathrm{hr}$. gave the aglucone, which was extracted with ether. 3:4'-Dimethoxy-5-hydroxystilbene $\left(0 \cdot 3\right.$ g.) crystallized from light petroleum (b.p. $\left.80-100^{\circ}\right)$ in plates, m.p. 115-116 ${ }^{\circ}$ (Found: C, 75.0; H, 6.1; OMe, 23.6. $\mathrm{C}_{16} \mathrm{H}_{18} \mathrm{O}_{3}$ requires $\mathrm{C}, 75 \cdot 0 ; \mathrm{H}, 6.3 ; \mathrm{OMe}, 24 \cdot 2 \%$ ). This compound differed from authentic 3:5-dimethoxy-4'hydroxystilbene, m.p. $87-88^{\circ}$, which was prepared by decarboxylation of 3:5-dimethoxy-4'-hydroxystilbene- $\beta$-carboxylic acid.

\section{RESULTS}

The ether-soluble phenols of the heartwood of Eucalyptus wandoo are not directly extractable with ether, since these compounds are embedded in ether-insoluble membrane substances. When the heartwood was extracted with methanol, the methanolic extract transferred to water and the resulting aqueous solution extracted with ether, nearly $4 \%$ of the wood was obtained as ethersoluble phenols. The ether-soluble pinosylvin extractives of Pinus spp. behave similarly, and they, too, are laid down within ether-insoluble membrane substances (Hägglund, Holmberg \& Johnson, 1936).

A two-dimensional chromatogram of the ethersoluble phenols showed the presence of eight constituents (Fig. 1). Three of these were chromatographically indistinguishable from chlorogenic acid, catechin or gallic acid and $p$-coumarylquinic acid respectively. Three of the remaining substances (spots 4, 6 and 7 in Fig. 1) showed an intense-blue fluorescence in ultraviolet light and their $R_{F}$ values and colour reactions were not those of known naturally occurring coumarins. The hydroxystilbenes (spots 4, 6, 7) gave a red compound with tetrazotized benzidine.

Compound $\mathrm{B}_{2}$, which exhibited absorption bands at 220 and $305 \mathrm{~m} \mu$, afforded a saturated dihydrocompound, $\mathrm{C}_{14} \mathrm{H}_{14} \mathrm{O}_{3}$, the spectrum of which showed a single absorption band at $280 \mathrm{~m} \mu$. The fluorescence of compound $\mathrm{B}_{2}$ was quenched by hydrogenation. This spectral shift and the quenching of the fluorescence on hydrogenation are characteristic of the hydroxystilbenes. In Table 2, compound $B_{2}$ is compared with a hydroxystilbene

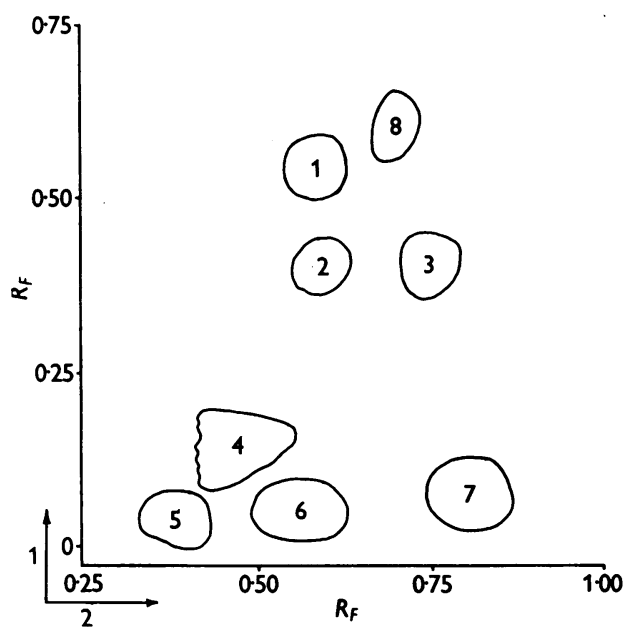

Fig. 1. Two-dimensional chromatogram of the ethersoluble phenols. The chromatogram was run first in $\mathrm{N}$-acetic acid, followed by butan-1-ol-acetic acid-water (6:1:2, by vol.). Spots located by $\mathrm{FeCl}_{3}-\mathrm{K}_{3} \mathrm{Fe}(\mathrm{CN})_{6}: 1$, chlorogenic acid; 2, catechin and gallic acid; 3 , unknown; 4, compound $B_{1} ; 5$, ellagic acid; 6 , unknown; 7 , compound $\mathrm{B}_{2} ; 8, p$-coumarylquinic acid.

Table 2. Comparison of the compound of Takaoka $(1940 a, c)$ with compourd $B_{2}$

Takaoka's compound

Crystal form

M.p.

Colour with $\mathrm{FeCl}_{s}$

Triacetate

Trimethyl ether $261^{\circ}$

Dark green

Needles, m.p. 114-116

Crystals, m.p. 56-57
Compound $\mathbf{B}_{2}$

Needles

$264^{\circ}$

Not significant

Needles, m.p. 118-119 ${ }^{\circ}$

Plates, m.p. 55-57 
which was isolated (Takaoka, 1940a,c) from a species of Veratrum (Liliaceae), and which was shown to be 3:5:4'-trihydroxystilbene (Takaoka, $1940 a, c)$. The comparison is a close one, and the melting points and the colours with ferric chloride suggest that the material isolated in the present work is purer. The green colour described by Takaoka is incompatible with his proposed structure and probably due to slight contamination. The mixed melting point of compound $\mathbf{B}_{2}$ and synthetic 3:5:4'-trihydroxystilbene showed that these substances were identical. 3:5:4'-Trihydroxystilbene was isolated in $1.0 \%$ yield by wt. from a mixture of the whole heartwood from different trees.

The ultraviolet-absorption spectra of compound $\mathrm{B}_{1}$ and its dihydro derivative, $\mathrm{C}_{20} \mathrm{H}_{24} \mathrm{O}_{8}$, are identical with those of compound $\mathrm{B}_{2}$ and its dihydro derivative respectively. It follows that compound $\mathrm{B}_{1}$ is also a hydroxystilbene. Oxidative degradation of the hexa-acetate of compound $B_{1}$ yielded $p$-hydroxy- and 3:5-dihydroxy-benzoic acid. Acid hydrolysis of compound $\mathrm{B}_{2}$ afforded 1 mol.prop. of 3:5:4'-trihydroxystilbene and $1 \mathrm{~mol}$.prop. of glucose. Compound $B_{1}$ is therefore $a$ monoglucose derivative of $3: 5: 4^{\prime}$-trihydroxystilbene, and the lack of reducing properties of compound $B_{1}$ suggests linkage through carbon atom $\mathrm{C}_{(\mathbf{1})}$ of the glucose residue. Hydrolysis of the glucoside and of the dihydroglucoside by emulsin showed that the glucoside linkage is in the $\beta$ configuration in relation to carbon atom $C_{(1)}$ of the glucose residue. The rotations of compound $B_{1}$ and of its hexa-acetate accord with those which have been recorded for phenol $\beta$-D-glucosides and their acetates (Elsner, 1935; Jermyn, 1955). Compound $B_{1}$ is therefore a $\beta$-D-glucoside of 3:5:4' -trihydroxystilbene. That the hydroxyl group in the 3-position of the aglucone may be implicated in the glucoside linkage is suggested by the slow response of the glucoside $B_{1}$ to vanillin reagent. This is confirmed by hydrolysis of the partially methylated glucoside which gave 3:4'-dimethoxy -5-hydroxystilbene, which differed in melting point from an authentic specimen of the isomeric 3:5-dimethoxy-4'-hydr- oxystilbene. 3:5:4'-Trihydroxystilbene-3 $\beta-\mathrm{D}-\mathrm{glu}$ coside was isolated in $0.1 \%$ yield by wt. from a mixture of the whole heartwood from different trees.

\section{DISCUSSION}

The simultaneous occurrence of 3:5:4'-trihydroxystilbene and its 3 - $\beta$-glucoside in mixed drillings from the heartwood of Eucalyptus wandoo Blak. (syn. E. redunca Schau, var. elata) raises the problem of the origin of these compounds and of their translocation to this tissue. Taxifolin-3' $-\beta$ glucoside has been found in the needles, cambium and sapwood of Pseudotsuga taxifolia, and in the wood or bark of Larix occidentalis, Picea sitchensis and Thuja plicata by Hergert \& Goldschmid (1958). These workers suggest that taxifolin is synthesized in the needles, where it is present as the glucoside which is translocated downwards through the inner bark and transversely via the rays to the heartwood and outer bark. Taxifolin-3'- $\beta$-glucoside is hydrolysed to the aglucone by a $\beta$-glucosidase which is located at or near the sapwood-heartwood and inner-outer bark boundaries. This translocation mechanism would account for the concomitance of piceatannol $\left(2: 5: 6: 3^{\prime}: 4^{\prime}\right.$ - pentahydroxy - 3:4 - tetramethylenestilbene) (Grassmann, Endres \& Pauckner, 1958) and piceatannol glucoside (2:6:4'-trihydroxy3:4 - tetramethylenestilbene - 5:3' - diglucoside) (Endres, 1958) in the stembark of Picea excelsa. The presence of such glycolytic enzymes in the tissues of forest trees has been demonstrated. Thus Zimmermann (1958) has described an $\alpha$-galactosidase which is attached to the cytoplasm of sieve tubes, and Pridham (1957 and unpublished work) has observed the presence of glycolytic enzymes, including a $\beta$-glucosidase in addition to an $\alpha$ galactosidase, in the cambial and sapwood tissues of aspen (Populus grandidentata, P. tacamahaca and $P$. tremuloides). Similar considerations may apply to the hydroxystilbenes of Eucalyptus wandoo heartwood, but the fact that the stilbene- $\beta$-Dglucoside occurs throughout a transverse section through the heartwood (Table 3) suggests that $\beta$ glucosidases are absent from the heartwood and

Table 3. Distribution of extractives and hydroxystilbenes in a transverse section through a 100-year-old primary limb (25 cm. radius)

\begin{tabular}{|c|c|c|c|c|}
\hline \multirow[b]{2}{*}{$\begin{array}{l}\text { Location in the } \\
\text { transverse section }\end{array}$} & \multirow[b]{2}{*}{$\begin{array}{l}\text { Distance from } \\
\text { centre } \\
\text { (cm.) }\end{array}$} & \multirow[b]{2}{*}{$\begin{array}{c}\text { Extractives } \\
(\%)\end{array}$} & \multicolumn{2}{|c|}{$\begin{array}{l}\text { Proximate amounts determined by } \\
\text { comparative paper chromatography }\end{array}$} \\
\hline & & & $\begin{array}{c}\text { 3:5:4'-Trihydroxy- } \\
\text { stilbene } \\
\text { (\%) }\end{array}$ & $\begin{array}{c}\text { 3:5:4'-Trihydroxy- } \\
\text { stilbene-3- } \beta \text {-D- } \\
\text { glucoside } \\
(\%)\end{array}$ \\
\hline Sapwood & 24 & $6 \cdot 1$ & Absent & Absent \\
\hline Heartwood & 23 & $25 \cdot 6$ & $0 \cdot 6$ & $1 \cdot 2$ \\
\hline Heartwood & 14 & $21 \cdot 3$ & $1 \cdot 0$ & $0 \cdot 1$ \\
\hline Heartwood & 0 & $16 \cdot 2$ & $1 \cdot 5$ & 0.04 \\
\hline
\end{tabular}


sapwood of this tree, and the absence of this stilbene glucoside from the sapwood suggests that it is rapidly transported via the rays through this narrow zone (of sapwood). Alternatively, these hydroxystilbenes may be formed from nonaromatic precursors at the sapwood-heartwood boundary (Wise \& Jahn, 1953).

3:5-Dihydroxy- and 3-hydroxy-5-methoxy-stilbene cause pine heartwood to resist wood-rotting fungi and insects. The activity of the stilbenes against these fungi is between 10 and 30 times greater than that of phenol (Erdtman \& Rennerfelt, 1944; Rennerfelt, 1943; 1944a-c; 1946). Wood which had been treated with a dilute solution of 3-hydroxy-5-methoxystilbene remained uneaten by the termite Cryptotermes brevis Walker after 4-5 years (Wolcott, 1951). Professor H. Erdtman (personal communication) has suggested that the presence of hydroxystilbenes in dicotyledonous heartwood confers similar protection, and that the presence of such hydroxystilbenes may have contributed to the successful survival of these trees during evolution. The antifungal properties have been demonstrated of $3: 5: 2^{\prime}: 4^{\prime}$-tetrahydroxystilbene (Barnes \& Gerber, 1955), which occurs in the heartwood of Maclura aurantica (Moraceae, see Table 1), and of 3:5-dimethoxy-4'-hydroxystilbene (King, Cotterill, Godson, Jurd \& King, 1953), which occurs in the heartwoods of Pterocarpus spp. (Leguminosae, see Table 1).

The occurrence in other Eucalyptus spp. of such flavonoids as aromadendrin [in $E$. calophylla R.Br. and $E$. corymbosa Sm. (syn. E. gummifera (Gaertn.) Hochr.)] (Hillis, 1952; Maiden \& Smith, 1895; Smith, 1896), aromadendrin-7-O-methyl ether (in $E$. maculata Hook) (Gell, Pinhey \& Ritchie, 1958), kaempferol (in $E$. calophylla) (Hillis, 1952) and naringenin (in E. maculata) (Gell et al. 1958), which are related to the 3:5:4'-trihydroxystilbenes in the same way as the flavonoids of the genus Pinus are related to the 3:5-dihydroxystilbenes, recalls Erdtman's (1956) proposal for their ontogenesis. Since the use of ${ }^{14} \mathrm{C}$-labelled cinnamic acid and shikimic acid and L-phenylalanine (Geissmann \& Swain, 1957; Underhill, Watkin \& Neish, 1957; Watkin, Underhill \& Neish, 1957) has shown that the phloroglucinol ring of such flavonoids as quercetin originates direct from acetate metabolism, and that the remaining phenylpropane residue of the C-skeleton is derived from the shikimic acid metabolic pathway, it follows that the resorcinol ring of 3:5-dihydroxy-and 3:5:4'-trihydroxy-stilbene also originates from acetate and that the remaining phenylethane residue of their C-skeleton is produced from the shikimic acid metabolic pathway, if Erdtman's ontogenetic suppositions apply to the Pinaceae and Myrtaceae respectively.

\section{SUMMARY}

1. Two hydroxystilbenes have been isolated from the ether-soluble extractives of Eucalyptus wandoo heartwood by cellulose- and polyamidecolumn chromatography.

2. One of the hydroxystilbenes has been identified as 3:5:4'-trihydroxystilbene and the other as 3:5:4'-trihydroxystilbene-3- $\beta$-D-glucoside.

3. In $E$. wandoo heartwood, the $3: 5: 4^{\prime}$-trihydroxystilbenes are laid down within ether-insoluble membrane substances.

4. The translocation, function and ontogenesis of the 3:5:4'-trihydroxystilbenes is discussed.

The authors thank the Director and Council of the British Leather Manufacturers' Research Association for permission to publish this paper. We also thank Industrial Extracts Ltd., of Perth, Western Australia, for a gift of the plant material and for a grant which defrayed a part of the cost of this work, Professor W. Grassmann, München, 15, Max-Planck-Institut für Eiweiss-und Ledırforschung, Schillerstrasse, 25, for a gift of Perlonpulver 'feinst', and Professor F. Wessely, Chemisches Institut der Universität Wien, Wien IX, Währinger Strasse, 38, for a gift of 3:5dimethoxy- $4^{\prime}$-hydroxystilbene- $\beta$-carboxylic acid.

\section{REFERENCES}

Barnes, R. A. \& Gerber, N. N. (1955). J. Amer. chem. Soc. 77, 3259.

Elsner, H. (1935). In Kurzes Handbuch der Kohlenhydrate, 4th ed., p. 271 et seq. Leipzig: Johann Ambrosius Barth Verlag.

Endres, H. (1958). Chem. Ber. 91, 636.

Erdtman, H. (1956). Sci. Proc. R. Dublin Soc. 27, 129.

Erdtman, H. \& Rennerfelt, E.(1944). Svensk PappersmasseTidn. 47, 45.

Geissmann, T. A. \& Swain, T. (1957). Chem. \& Ind. p. 984. Gell, R. J., Pinhey, J. T. \& Ritchie, E. (1958). Aust. J. Chem. 11, 372.

Grassmann, W., Deffner, G., Schuster, E. \& Pauckner, W. (1956). Chem. Ber. 89, 2523.

Grassmann, W., Endres, H. \& Pauckner, W. (1958). Chem. Ber. 91, 134.

Grassmann, W., Endres, H., Pauckner, W. \& Mathes, H. (1957). Chem. Ber. 90, 1125.

Hägglund, E. (1941). Öst. Chem.Ztg. 44, 104.

Hägglund, E., Holmberg, J. \& Johnson, T. (1936). Svensk PappersförädlTidskr. Special no. 37.

Hathway, D. E. (1958). Biochem. J. 70, 34.

Hathway, D. E. \& Seakins, J. W. T. (1958). Biochem. J. $70,155$.

Hergert, H. L. \& Goldschmid, O. (1958). J. org. Chem. 23, 700.

Hillis, W. E. (1952). Aust. J. sci. Res. Ser. A, 5, 379.

Jermyn, M. A. (1955). Aust. J. Chem. 8, 403.

Kawamura, J. (1938). J. pharm. Soc. Japan, 58, 405.

King, F. E., Cotterill, C. B., Godson, D. H., Jurd, L. \& King, T. J. (1953). J. chem. Soc. p. 3693.

King, F. E. \& Grundon, M. F. (1949). J. chem. Soc. p. 3348. King, F. E., King, T. J., Godson, D. H. \& Manning, L. C. (1956). J. chem. Soc. p. 4477. 
Koch, J. E. \& Krieg, W. (1938). Chem.-tech. Z. 62, 140.

Linstedt, G. (1950). Acta chem. scand. 4, 448.

Maiden, J. H. \& Smith, H. G. (1895). J. Roy. Soc. N.S.W. 29, 30.

Mann, F. G. \& Saunders, B. C. (1938). In Practical Organic Chemistry, 2nd ed., p. 365. London: Longmans, Green and Co.

Mongolsuk, S., Robertson, A. \& Towers, R. (1957). J. chem. Soc. p. 2231.

Pridham, J. B. (1957). Analylt. Chem. 29, 1167.

Rennerfelt, E. (1943). Svensk bot. Tidskr. 37, 83.

Rennerfelt, E. (1944a). Medd. Skogsförsöksanst. Stockh. 33, 331.

Rennerfelt E. (1944b). Skogsägaren, 20, 84.

Rennerfelt E. (1944c). Skogsägaren, 20, 91.

Rennerfelt, E. (1946). Medd. Skogsförsöksanst. Stockh. 34, 391.

Smith, H. G. (1896). J. Roy. Soc. N.S.W. 30, 15.
Späth, E. \& Schläger, J. (1940). Ber. dtsch. chem. Ges. 73, 881.

Stark, J. B., Goodban, A. E. \& Owens, H. S. (1951). Analyt. Chem. 23, 413.

Takaoka, M. (1940a). J. Fac. Sci. Hokkaido Univ. (3), 3, 1.

Takaoka, M. (1940b). Proc. imp. Acad. Japan, 16, 405.

Takaoka, M. (1940c). J. chem. Soc. Japan, 61, 30.

Takaoka, M. (1940d). J. chem. Soc. Japan, 61, 1067.

Underhill, E. W., Watkin, J. E. \& Neish, A. C. (1957). Canad. J. Biochem. Physiol. 35, 219.

Watkin, J. E., Underhill, E. W. \& Neish, A. C. (1957). Canad. J. Biochem. Physiol. 35, 229.

Wise, L. E. \& Jahn, E. C. (1953). In Wood Chemistry, 2nd ed., pp. 15, 16, 638 et seq. New York: Reinhold.

Wolcott, G. N. (1951). J. econ. Ent. 44, 263.

Zimmermann, M. H. (1958). In The Physiology of Forest Trees, p. 381. Ed. by Thimann, K. V. New York: The Ronald Press Co.

\title{
A Study of Vitamin $B_{12}$ Protection in Experimental Thyrotoxicosis in the Rat
}

\author{
By D. K. KASBEKAR, W. V. LAVATE, D. V. REGE aNd A. SREENIVASAN \\ Department of Chemical Technology, University of Bombay, India
}

\section{(Received 3 March 1958)}

Occurrence of vitamin $B_{12}$ deficiency in animals is not common. The maternal carry-over of the vitamin to the young and a substantial contribu. tion to the host by the intestinal microflora render it difficult to induce experimental vitamin $B_{12}$ deficiency even on strictly vitamin $B_{12}$-free diets. $A$ widely practised method of producing such a deficiency is by the use of thyroid-active materials like iodinated casein. Young growing animals fed on diets supplemented with thyroprotein were therefore used by early investigators (Zucker \& Zucker, 1950) for assays of liver preparations. In the presence of an ample supply of other nutrients, iodinated casein induces retardation of growth and subsequently a high mortality, which are partially counteracted by supplementation of the ration with vitamin $B_{12}$ (Emerson, 1949; Cuthbertson, 1949; Sure \& Easterling, 1950; Graham, Reichstein, Watson \& Hier, 1952).

Relatively little is known, however, about the mode of action of thyroxine and the counteraction of its effects by vitamin $B_{12}$ in intermediary metabolism. Recent work of Maley \& Lardy (1955) suggests that the thyroid hormone probably acts by impairing the efficiency of oxidative phosphorylation. However, the hormone had no direct effect on the enzymes of oxidative phosphorylation, as shown by Cooper \& Lehninger (1956) with digitonin preparations from mitochondria. It is possible therefore that damage to the mitochondrial morphology may be one of the reasons for the observed derangements. Fatterpaker, Marfatia \& Sreenivasan (1955) studied certain model conjugation systems, such as acetylation of $p$-aminobenzoic acid and benzoylation of glycine, and observed that in the hyperthyroid animal there is a marked reduction in the efficiency of coupling of the energy generating and -utilizing mechanisms. The counteraction of this condition by vitamin $B_{12}$ led them to suggest that the primary manifestation of thyrotoxicosis is a deficiency of vitamin $B_{12}$ and that vitamin $B_{12}$ probably acts by restoration, in part at least, of oxidative phosphorylation.

The work presented here deals with the vitamin $B_{12}$ reserves in tissues of animals fed on diets supplemented with iodinated casein. A pronounced lowering of liver and blood vitamin $B_{12}$ is shown to be paralleled by a major derangement in the metabolism of soluble sulphydryl compounds in the liver. Observations on centrifugally separated cell fractions also indicate damage to the mitochondria. All these derangements are corrected by vitamin $B_{12}$, which suggests that vitamin $B_{12}$ probably exerts protection through the maintenance of mitochondrial morphology and levels of liver sulphydryl compounds.

\section{EXPERIMENTAL}

Induction of thyrotoxicosis in rats. Weanling rats (Wistar strain) 3-4 weeks old and weighing about $40 \mathrm{~g}$. were used. They were fed on a purified diet of the following composition (per cent, by wt.): ethanol-extracted casein 10, starch 